\title{
CORRECTION
}

\section{Correction to: Long-term climatic water availability trends and variability across the African continent}

\section{Charles Onyutha ${ }^{1}$ (1)}

Published online: 4 August 2021

(c) Springer-Verlag GmbH Austria, part of Springer Nature 2021

\section{Correction to: Theoretical and Applied Climatology} https://doi.org/10.1007/s00704-021-03669-y

In this article, typographical and minor mistakes should be corrected in sections 1, 2.1.2, 2.2, 2.4.1, 3.2 and Eqs. 8-10.

The original article has been corrected.

Publisher's note Springer Nature remains neutral with regard to jurisdictional claims in published maps and institutional affiliations.

The original article can be found online at https://doi.org/10.1007/ s00704-021-03669-y

Charles Onyutha

conyutha@kyu.ac.ug; conyutha@gmail.com

1 Department of Civil and Environmental Engineering,

Kyambogo University, P.O. Box 1, Kyambogo, Kampala,

Uganda 